\title{
Running has Differential Effects on NPY, Opiates, and Cell Proliferation in an Animal Model of Depression and Controls
}

\author{
Astrid Bjørnebekk², Aleksander A Mathé*,1 and Stefan Brené ${ }^{1,2}$ \\ 'Karolinska University Hospital-Huddinge, Division of Psychiatry, Karolinska Institutet, Stockholm, Sweden; ${ }^{2}$ Department of Neuroscience, \\ Karolinska Institutet, Stockholm, Sweden
}

\begin{abstract}
Physical activity has documented beneficial effect in treatment of depression. Recently, we found an antidepressant-like effect of running in an animal model of depression, the Flinders Sensitive Line (FSL) and demonstrated that it was associated with increased hippocampal cell proliferation. In this study, we analyzed levels of mRNAs encoding the neuropeptide Y (NPY) and the opioid peptides dynorphin and enkephalin in hippocampus and correlated these to cell proliferation in the FSL and in the 'nondepressed' Flinders Resistant Line (FRL) strain, with/without access to running wheels. Running increased NPY mRNA in dentate gyrus and the CA4 region in FSL, but not in FRL rats. NPY mRNA increase was correlated to increased cell proliferation in the subgranular zone of dentate gyrus. Baseline dynorphin and enkephalin mRNA levels in the dentate gyrus were lower in the FSL compared to the FRL strain. Running had no effect on dynorphin and enkephalin mRNAs in the FSL strain but it decreased dynorphin mRNA, and there was a trend to increased enkephalin mRNA in the FRL rats. Thus, it would appear that the CNS effects of running are different in 'depressed' and control animals; modification of NPY, a peptide associated with depression and anxiety, in depressed animals, vs effects on opioids, associated with the reward systems, in healthy controls. Our data support the hypothesis that NPY neurotransmission in hippocampus is malfunctioning in depression and that antidepressive treatment, in this case wheel running, will normalize it. In addition, we also show that the increased NPY after running is correlated to increased cell proliferation, which is associated with an antidepressive-like effect.

Neuropsychopharmacology (2006) 3 I, 256-264. doi:I 0.1 038/sj.npp. I 300820; published online 20 July 2005
\end{abstract}

Keywords: depression; hippocampus; Flinders Sensitive Line; neuropeptide Y; opioid peptides; physical activity

\section{INTRODUCTION}

Exercise promotes physical health and is also an efficient antidepressant in depressed patients (Blumenthal et al, 1999; Martinsen et al, 1985; Strawbridge et al, 2002) as well as in an animal model of depression (Bjørnebekk et al, 2005). In fact, in a recent follow-up study, continued exercise was more efficient in preventing depressive relapses than antidepressant medication (Babyak et al, 2000). However, the mechanisms by which exercise produces therapeutic effects are not understood. Running can also be reinforcing. For instance, rodents will leverpress to get access to running wheels and they develop preference for an environment that they associate with the aftereffects of wheel running (Belke, 1997; Iversen, 1993; Lett et al, 2001). Interestingly, an opioid receptor antagonist can block this effect, which suggests that endogenous opioid

* Correspondence: Dr AA Mathé, Karolinska University HospitalHuddinge, SE-|4I 86 Stockholm, Sweden, Tel: + 468524879 72, Fax: 46852488929 , E-mail: aleksander.mathe@cns.ki.se

Received 7 January 2005; revised 31 March 2005; accepted 13 April 2005

Online publication: 6 June 2005 at http://www.acnp.org/citations/ Npp060605050006/default.pdf peptides have a role in the reinforcing effects of running in rodents. Moreover, long-term running will cause neuroadaptive changes such as increased $\Delta \mathrm{FosB}$ and increased dynorphin levels in brain reward pathways that are similar to the adaptations that are seen after chronic administration of addictive drugs (Werme et al, 2002, 2000).

Neurogenesis in the adult mammalian brain was described over 40 years ago (Altman, 1962), but remained controversial for a long time (Gross, 2000). The sites of proliferation are well characterized in two areas of the brain, the subventricular zone and in the subgranule zone (SGZ) of the dentate gyrus in hippocampus. Antidepressant treatment modalities such as selective serotonin reuptake inhibitors (SSRI), for example fluoxetine; tricyclics, for example desipramine; and electroconvulsive treatment (ECT), and also running in running wheels, all cause increased cell proliferation and neurogenesis in the SGZ (Fabel et al, 2003; Malberg et al, 2000; Santarelli et al, 2003; van Praag et al, 1999).

The Flinders Sensitive Line (FSL) and Flinders Resistant Line (FRL) are used as a genetic animal model of depression and controls, respectively. Selective breeding of SpragueDawley (SD) rats with regard to their response to the anticholinesterase agent diisopropylfluorophosphate (DFP) 
(Overstreet et al, 1979; Russell et al, 1982) generated a sensitive (FSL) and a resistant strain (FRL). Subsequently, it was realized that FSL exhibits a phenotype that mimics a number of symptoms seen in human depression (Husum et al, 2001; Overstreet, 1993; Pucilowski et al, 1993). The FSL strain shows good face and predictive validity as a model of depression and in assessment of antidepressant treatments (Overstreet, 1993, 1995). Recently, we found that the antidepressant effect of exercise in FSL was associated with increased hippocampal cell proliferation (Bjørnebekk et al, 2005). Thus, increased cell proliferation and neurogenesis in the SGZ appear to be one common feature of antidepressant treatments, including running.

Several different molecules such as trophic factors and neuropeptides are suggested to have an important role in the control of cell proliferation, neurogenesis, differentiation, and cell survival. In the adult olfactory epithelium neuropeptide Y (NPY) has been demonstrated to promote neuronal proliferation (Hansel et al, 2001a). Moreover, clinical and experimental evidence suggests a role for NPY in the pathophysiology of depression (Mathé and Gruber, 2004; Nikisch et al, 2005; Widerlov et al, 1988). Previous clinical studies have reported decreased NPY levels in brain tissue from suicide victims (Widdowson et $a l, 1992$ ) and in the cerebrospinal fluid (Heilig et al, 2004) and plasma (Nilsson et al, 1996) of depressed patients compared to controls. In rats intracerebroventricular (i.c.v) administration of NPY is anxiolytic (Britton et al, 1997; Heilig et al, 1989) and decreases immobility in the Porsolt swim test (PST) (Mathé and Gruber, 2004; Stogner and Holmes, 2000). Further, the effects of NPY in the PST are dose dependently blocked by an NPY-Y1 receptor antagonist (Mathé and Gruber, 2004). In genetic animal models of depression, the Fawn Hooded rats and FSL, decreased levels of hippocampal NPY were found (Jiménez Vasquez et al, 2000a, b). Furthermore, NPY is also decreased in rat models that mimic environmental stress, such as maternally separated rats (Husum and Mathé, 2002; Jiménez-Vasquez et al, 2001; Woldbye et al, 2002). Conversely, antidepressant treatments, for example, chronic but not single ECT in humans and electroconvulsive stimuli (ECS) in rodents, lithium and antidepressant drugs (Stenfors et al, 1989; Mathé et al, 1990, 1994, 1996; Mathé, 1999; Caberlotto et al, 1999). Cumulatively, these results indicate that NPY might be involved in affective disorders and their treatments via a mechanism that could include regulation of cell proliferation and neurogenesis in hippocampus. However, it remains unclear if manipulating NPY clinically would have antidepressive and neurogenic effect in depressed individuals (Mathé et al, 2005).

The opioid peptides dynorphin and enkephalin are expressed with high levels in dentate gyrus and described to have a putative role in the control of mood (Filliol et al, 2000) as well as in regulation of cell proliferation and neurogenesis of adult hippocampal progenitors (Persson et al, 2003; Shirayama et al, 2004). These endogenous opioid peptides are also highly expressed in the granule cell layer of hippocampus, a brain region involved in memory formation. Virtually all neurons in the granule cell layer express dynorphin and a subset of neurons within this layer also expresses enkephalin.
In hippocampus, dynorphin has an inhibitory effect on long-term potentiation (LTP) (Wagner et al, 1993), but less is known about its effects in modifying affective states. In contrast to dynorphin, enkephalin potentiates LTP in hippocampus (Bramham et al, 1991). Most likely, enkephalin binds to $\mathrm{mu}$ and delta receptors on inhibitory GABAergic interneurons within the CA3 and CA1, thereby facilitating LTP in hippocampus via disinhibition of excitatory pyramidal neurons within CA3 and CA1. Based on results from animal studies, it was suggested that delta receptors have a potential in treatment of depression (Broom et al, 2002). Thus, mice with a deletion of delta receptors have increased anxiety and 'depression'. Moreover, delta receptor agonists and enkephalinase inhibitors have an antidepressant-like effect in animal studies (Tejedor-Real et al, 1998).

In a previous study we showed that FSL rats have lower basal cell proliferation compared to FRL rats. When placed in single cages with free access to running wheels, the FSL rats develop a lower daily running than the FRL rats. After 5 weeks, the distances covered were approximately 3 and $7 \mathrm{~km}$ /day by the FSL and FRL rats, respectively. Running during 30 days had an antidepressant-like effect as tested in the PST and also increased cell proliferation in the FSL but not in the FRL rats (Bjørnebekk et al, 2005). In contrast, running increased BDNF levels in the FRL but had no effect in the FSL rats. The aim of this work was to, in the same animal model, study the effects of running on regulation of NPY and the opioid peptides dynorphin and enkephalin in hippocampus and to correlate possible neuropeptide changes with the effects of running on a measure of depression (the PST) and cell proliferation.

\section{MATERIALS AND METHODS}

\section{Wheel Running}

Male FSL rats $(n=16)$, and their controls, FRL $(n=16)$ were bred at the Karolinska Institute. All animal experiments were approved by the Ethical Committee for Animal Research in Stockholm. The animals were individually housed with either free access (FSL, $n=8$; FRL, $n=8$ ) or no access (FSL, $n=8$; FRL, $n=8$ ) to running wheels (diameter, $34 \mathrm{~cm}$; one revolution corresponding to $1.07 \mathrm{~m}$ ) during a period of 5 weeks (Figure 1). Running data were sampled

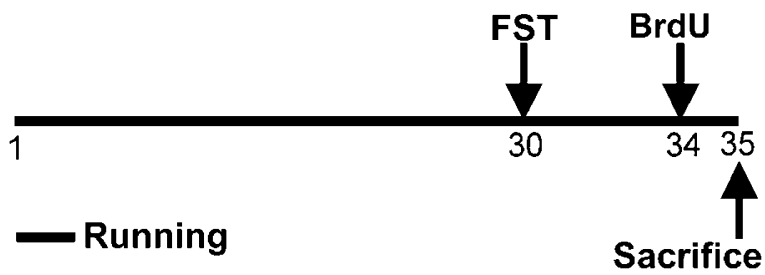

Figure I A schematic illustration of the experimental design. Runners $(N=16)$ had free access to the running wheels from experimental day I35. Control animals $(N=16)$ went through the same protocol except that they had no access to the running wheels. On day 30, a modified Porsolt swim test was performed on all animals $(n=32)$. On day 34 , all animals received four injections of $\mathrm{BrdU}(75 \mathrm{mg} / \mathrm{kg}$, i.p.) and were killed about $20 \mathrm{~h}$ after the last injection. 
48 times/day using a computer-based data system with a customized software (Werme et al, 1999). Animals had access to food and water ad libitum and were subjected to a controlled 12-h light:12-h dark-schedule (lights on at 0700). After 30 days of running, animals were analyzed in a modified version of Porsolt's swim test (see Bjørnebekk et al, 2005).

\section{5-bromo-2deoxyuridine (BrdU) Administration}

To evaluate cell proliferation, four injections of BrdU (75 mg/kg, i.p., Sigma) with $2 \mathrm{~h}$ intervals were administered 4 days after the swim test (Bjørnebekk et al, 2005). One FSL runner and one FSL control died after BrdU injections leaving seven FSL runners and seven FSL controls for histological analysis. The animals were killed about $20 \mathrm{~h}$ after the last injection (Figure 1). The brains were immediately removed and frozen at $-80^{\circ} \mathrm{C}$.

\section{BrdU Immunohistochemistry}

For the immunohistochemistry, coronal $40 \mu \mathrm{m}$ sections were collected with a cryostat throughout the hippocampal formation and temporarily stored in $-20^{\circ} \mathrm{C}$ freezer. Antibodies and dilutions used were: mouse $\alpha$-BrdU ( $1: 100$ DAKO A/S, Denmark), horse $\alpha$-mouse-biotin $(1: 200$ Vector, Burlingame, CA, USA). Immunohistochemistry for BrdU was performed as follows: sections were taken out of freezer $\left(-20^{\circ} \mathrm{C}\right)$ and postfixed for $10 \mathrm{~min}$ in $4 \%$ formaldehyde, rinsed in PBS $4 \times 5 \mathrm{~min}$, incubated $30 \mathrm{~min}$ in $2 \mathrm{M} \mathrm{HCl}$ at $37^{\circ} \mathrm{C}$, rinsed $3 \times 5 \mathrm{~min}$ in $\mathrm{PBS}$, and incubated for $1 \mathrm{~h}$ in blocking solution (horse serum $10 \%, 0.1 \%$ tween in PBS) at room temperature. This was followed by overnight incubation with mouse $\alpha$-BrdU at $4{ }^{\circ} \mathrm{C}$. On day 2 , the samples were rinsed $3 \times 30 \mathrm{~min}$ in $0.1 \%$ tween PBS, incubated with horse $\alpha$-mouse-biotin for $60 \mathrm{~min}$ at room temperature, rinsed again for $90 \mathrm{~min}$ in PBS $0.1 \%$ tween followed by $30 \mathrm{~min}$ in PBS only. The sections were then incubated for $40 \mathrm{~min}$ at room temperature with avidin-biotin-peroxidase complex ( $1: 100$ in PBS, Vectastain Elite, Vector, Burlingame, CA, USA), then rinsed in PBS for $1 \mathrm{~h}$, followed by peroxidase detection $\left(0.7 \mathrm{mg} / \mathrm{ml}\right.$, DAB dissolved in $\mathrm{H}_{2} \mathrm{O}$ ) (DAB Peroxidase Substrate, Sigma) for about $25 \mathrm{~s}$ per section. The sections were rinsed in PBS and stained with a hematoxylin solution (Vector).

\section{Stereology of BrdU Positive Cells}

For quantification of BrdU positive cells in the dentate gyrus, the unbiased optical fractionater counting procedure was performed (West et al, 1991). Coronal 40- $\mu$ m sections were taken throughout the hippocampus and every 15 th section $(600-\mu \mathrm{m}$ apart) (section sampling fraction (ssf)) was selected for analysis of the right dentate gyrus. On average, eight sections per animal were analyzed. An unbiased counting frame with known area was superimposed on the field of view by appropriate software (Stereologer ${ }^{\mathrm{TM}}$, SPA Inc.). The counting frames were systematically distributed with known $x$ and $y$ steps throughout the marked region from a random starting point. The area of the counting frame relative to the area associated with the $x$ and $y$ steps gives the second fraction (area sampling fraction (asf)). The height of the optical dissector relative to the thickness of the section results in the third fraction (height (h)/thickness (h)). The total number of neurons is given by

$$
N_{\text {total }}=\sum Q^{-} \frac{1}{\operatorname{ssf}} \frac{1}{\operatorname{asf}} \frac{t}{h}
$$

where $\sum Q^{-}$is the number of neurons counted in the dissectors. The dentate gyrus was manually outlined using a $\times 10$ lens. Cell counts were performed with a $\times 60$ lens (numerical aperture $=1.4$ ). Positive cells were counted if they where within the dissectors. Cells situated further than two cell body widths away from the base of the granular cell layer were defined as belonging to hilus, and thus not counted. Also, cells were excluded if they were situated in the uppermost focal plane. To estimate total number of BrdU cells per individual, a representative material of BrdU immunoreactive cells in the dentate gyrus of the left hemispheres was compared to that of the right hemispheres. $T$-tests showed that there were no differences in number of BrdU immunoreactive cells between the two hemispheres, and the total number of cells per individual was calculated.

\section{In Situ Hybridization}

Coronal brain sections $(40-\mu \mathrm{m})$ were cut on a cryostat at $-20^{\circ} \mathrm{C}$, and sections were thawed on glass slides. The hybridization cocktail contained $50 \%$ formamide, $4 \times$ SSC $(1 \times \mathrm{SSC}$ is, in $\mathrm{M}, \mathrm{NaCl}, 0.15$; sodium citrate, $0.015, \mathrm{pH} 7.0)$, $1 \times$ Denhardt's solution, $1 \%$ Sarcosyl, $0.02 \mathrm{M} \mathrm{Na}_{3} \mathrm{PO}_{4}, \mathrm{pH}$ 7.0, 10\% dextransulphate, $0.06 \mathrm{M}$ dithiothreitol, and $0.1 \mathrm{mg} /$ $\mathrm{ml}$ sheared salmon sperm DNA. Single-stranded oligonucleotide 48-mer DNA probes specific for dynorphin (296345) (Douglass et al, 1989), enkephalin (235-282) (Zurawski et al, 1986), and NPY (1671-1714) (Larhammar et al, 1987) mRNA were used. The probes were $3^{\prime}$-end labeled with $\alpha-{ }^{33}$ P-dATP (Dupont NEN, Wilmington, DE) using terminal deoxynucleotidyl transferase (Gibco) to a specific activity of approximately $1 \times 10^{9}$ c.p.m./mg. Hybridization was performed for $18 \mathrm{~h}$ in a humidified chamber at $42^{\circ} \mathrm{C}$. Following hybridization, the sections were rinsed $4 \times 20 \mathrm{~min}$ in $1 \times$ SSC at $60^{\circ} \mathrm{C}$ and subsequently in autoclaved water for $10 \mathrm{~s}$, dehydrated in alcohol, and air-dried. Thereafter, the slides were exposed to film (Kodak Biomax MR film, Kodak, Rochester, NY) for 5-12 days and developed. Films were scanned and optical density values quantified using appropriate software (NIH image analysis program, version 1.62). A ${ }^{14} \mathrm{C}$ step standard (Amersham, Buckinghamshire, UK) was included to calibrate optical density readings and convert measured values into nCi/g.

\section{Statistical Analysis}

Two-way MANOVA with planned comparison and Scheffe post hoc test was performed to analyze mRNA levels. To further investigate the relationship between treatment and outcome variables Persons product-moment correlation was calculated (Statistica). 


\section{RESULTS}

Basal Levels of NPY, Dynorphin, and Enkephalin mRNAs in Hippocampal Subregions and the Effect of 5 weeks of Running

To analyze the neurochemistry that underlies the adaptive differences between the 'depressed' FSL and the control FRL rats, mRNAs encoding NPY and the opioid neuropeptides dynorphin and enkephalin were analyzed in hippocampal subregions in single housed rats with/without access to running wheels.

Analyses of basal NPY mRNA levels in the two strains revealed similar levels of NPY mRNA in CA1 and CA3. In the dentate gyrus, NPY mRNA was lower in the FSL compared to FRL rats $(p<0.01)$. Running had no effect on NPY mRNA in CA1 and CA3 but it increased NPY mRNA in the CA4 and dentate gyrus in the FSL compared to the FRL rats $(p<0.05)$ (Figure 2). Baseline NPY mRNA levels did not differ between the dorsal and the ventral blade of the dentate gyrus, and running had no differential effect in
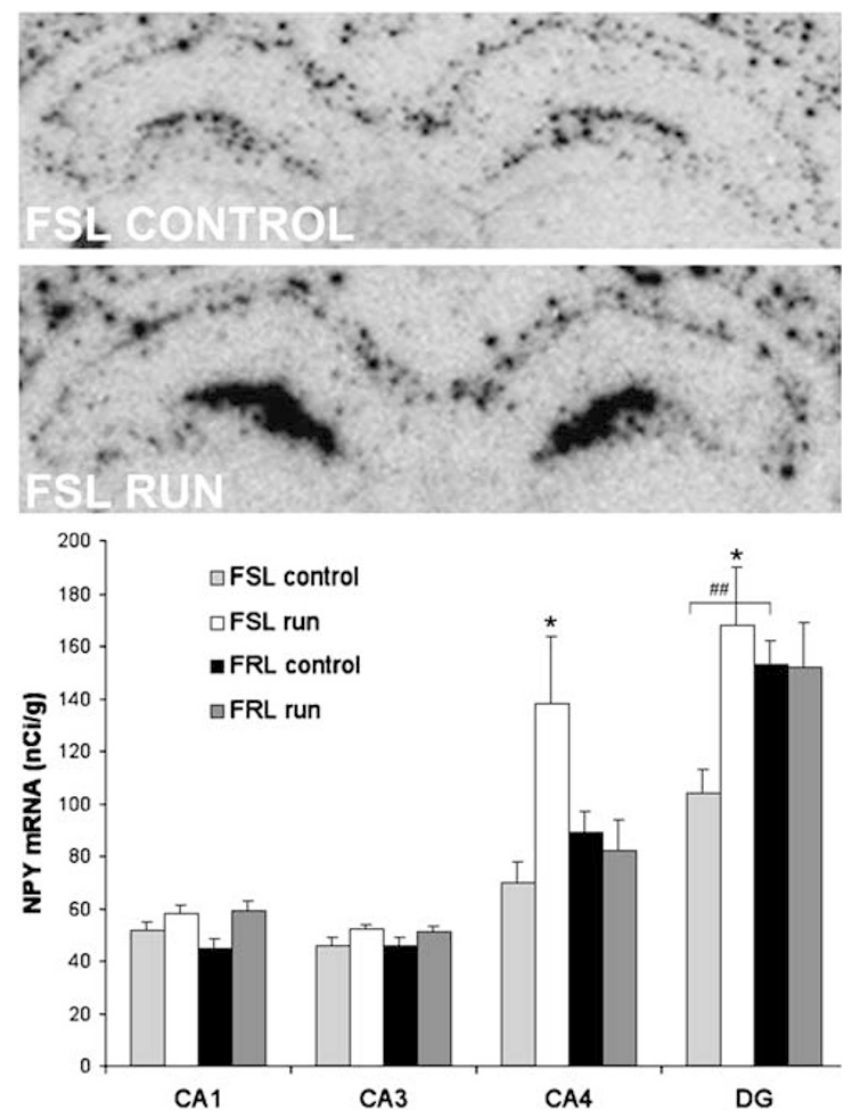

Figure 2 NPY mRNA expression in single housed FRL and FSL rats after 5 weeks of running. Upper panels show an in situ autoradiogram of NPY mRNA expression in hippocampus. A 48-mer oligonucleotide probe specific for NPY mRNA was used. Note the increase in NPY mRNA expression in the dentate gyrus and CA4 region of the hippocampus in FSL runners. Lower panel graphs show the levels of hippocampal NPY mRNA in FSL and FRL rats with/without access to running-wheels ( $n=6$-8/group). Analyses were performed approximately at the level of Bregma -3.30 . Values are means \pm SEM. ${ }^{\# \#} p<0.0$ I indicates a strain difference, ${ }^{*} p<0.05$ indicates significantly higher levels of NPY mRNA after running. Cal-4, fields of Ammon's horn; DG, dentate gyrus. dorsal $v s$ ventral blade (data not shown). In a recent study we showed that FSL rats have low cell proliferation that can be normalized by running (see Table 1, reviewing cell proliferation data from Bjørnebekk et al, 2005). Interestingly, NPY mRNA in the CA4 region and in the dentate gyrus was positively correlated to the number of proliferated BrdU-positive cells in the subgranular zone of dentate gyrus $(r=0.41, r=0.52, p<0.05)$ (Figure 3 ) (BrdU data from Bjørnebekk et al, 2005).

Dynorphin mRNA levels differed between the two strains in the dentate gyrus $(p<0.001)$, with lower levels in the FSL rats. In all groups the dynorphin mRNA levels were equally expressed in the dorsal and the ventral blade, and thus not separating the two regions (data not shown). Running decreased dynorphin mRNA in the FRL strain $(p<0.01)$ but not in the FSL strain (Figure 4). There was no correlation between cell proliferation and levels of dynorphin mRNA in hippocampus. Enkephalin mRNA levels were lower in the dorsal and in the ventral blade of the dentate gyrus $(p<0.01)$ in the FSL compared to FRL rats. There was a trend to an increase in the ventral blade of the dentate gyrus in FRL runners $(p=0.08)$ (Figure 5). Levels of enkephalin mRNA in hippocampus were not correlated to cell proliferation.

Pearson's correlations between immobility time in the PST (see Bjørnebekk et al, 2005) and the neuropeptides analyzed were not statistically significant for any hippocampal subregion (data not shown).

Table I Cell Proliferation in the Dentate Gyrus in FRL and FSL Rats with/without Access to Running Wheels

\begin{tabular}{lcl}
\hline & Control & \multicolumn{1}{c}{ Run } \\
\hline FRL & $100 \pm 19.36$ & $116 \pm 35.35$ \\
FSL & $25 \pm 1.86$ & $110 \pm 14$ \\
\hline
\end{tabular}

The FRL controls were arbitrarily denoted as I00\%. FSL controls have lower cell proliferation than FRL controls. Running increases cell proliferation in FSL rats to about the same level as FRL controls. For more details on cell proliferation data see Bjørnebekk et al (2005).

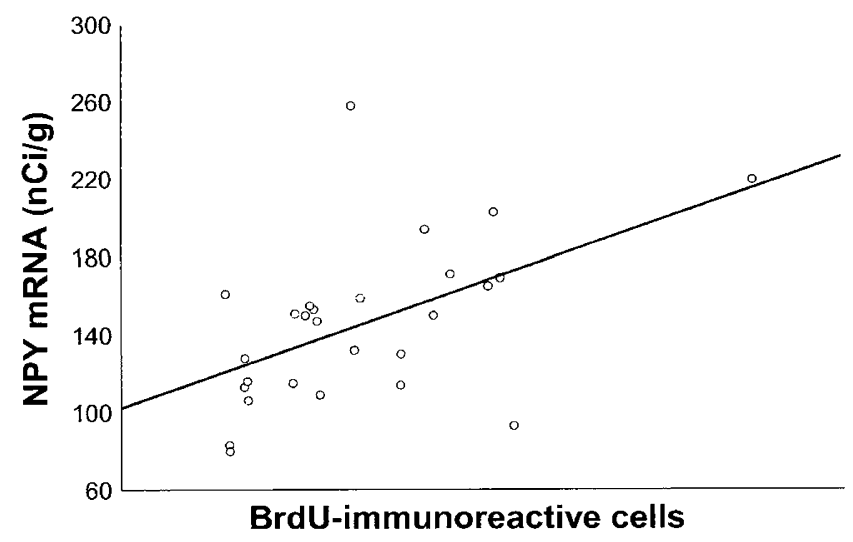

Figure 3 NPY mRNA levels in the dentate gyrus from FSL and FRL rats with/without access to running wheels correlate with the number of newly proliferated cells positive for BrdU-immunoreactivity in the subgranular layer of dentate gyrus. Each dot represents one rat $(n=27)(r=0.52$, $p<0.05$ ). 

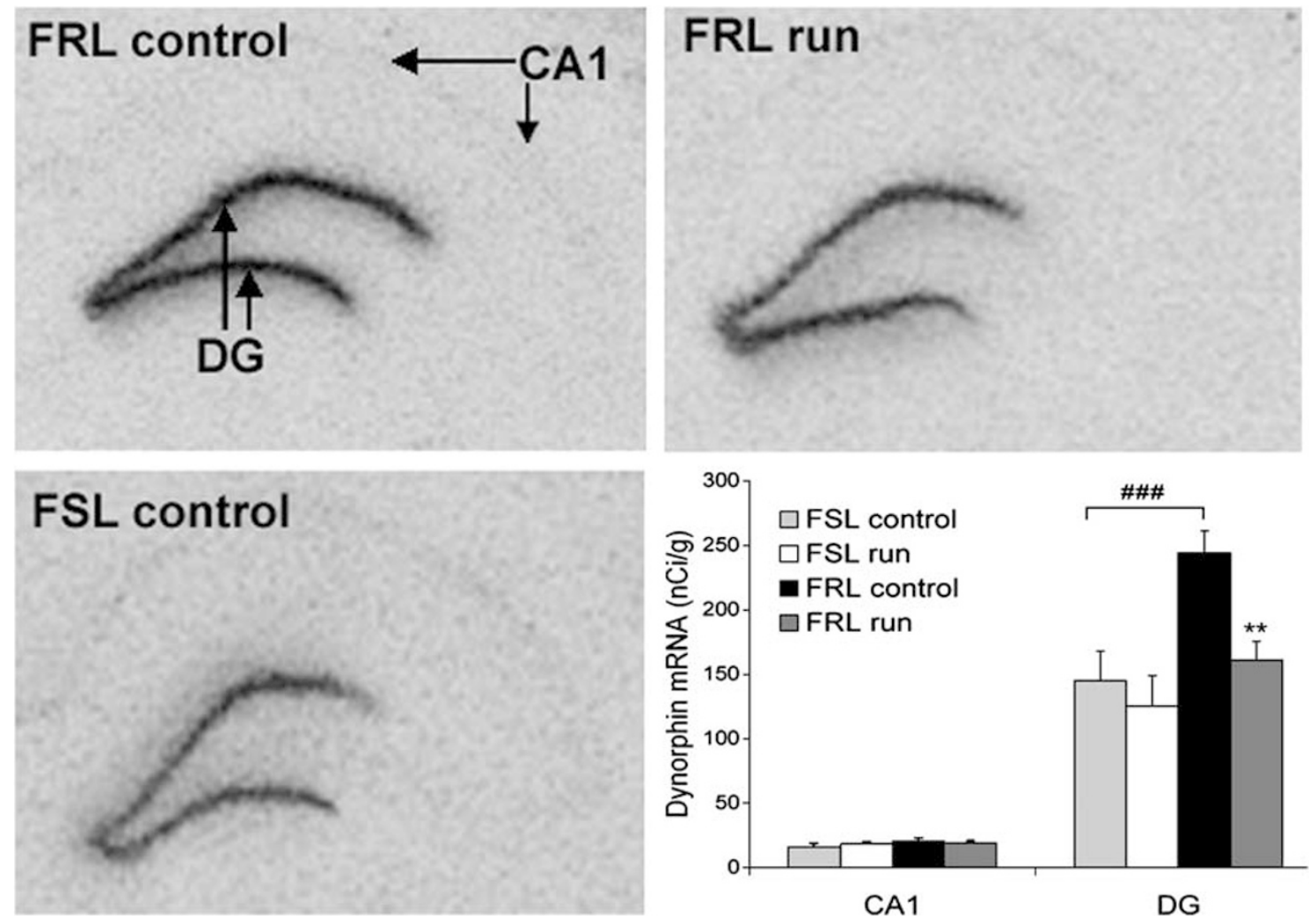

Figure 4 Hippocampal dynorphin mRNA expression in FSL and FRL rats after 5 weeks of running. In situ autoradiogram of dynorphin mRNA in the dentate gyrus of FSL and FRL rats and effect of running. Note the lower expression of dynorphin mRNA in FSL and a dynorphin mRNA decrease in the ventral and dorsal blade of the dentate gyrus in FRL rats after running. Bars illustrate dynorphin mRNA levels in hippocampal subregions in FSL and FRL rats with/without access to running wheels ( $n=6-8$ /group). FRL controls have a higher baseline level of dynorphin mRNA in the ventral and dorsal blade of the dentate gyrus than the FSL controls. Running decreases dynorphin mRNA levels in the dentate gyrus in FRL rats. Analyses were performed approximately at the level of Bregma -3.30 . Values are means \pm SEM. ${ }^{*} p<0.0$ I indicates a significant decrease in dynorphin mRNA levels after running. ${ }^{\# \# \#} p<0.00$ I indicates a strain difference. Cal, field of Ammon's horn; DG, dentate gyrus.

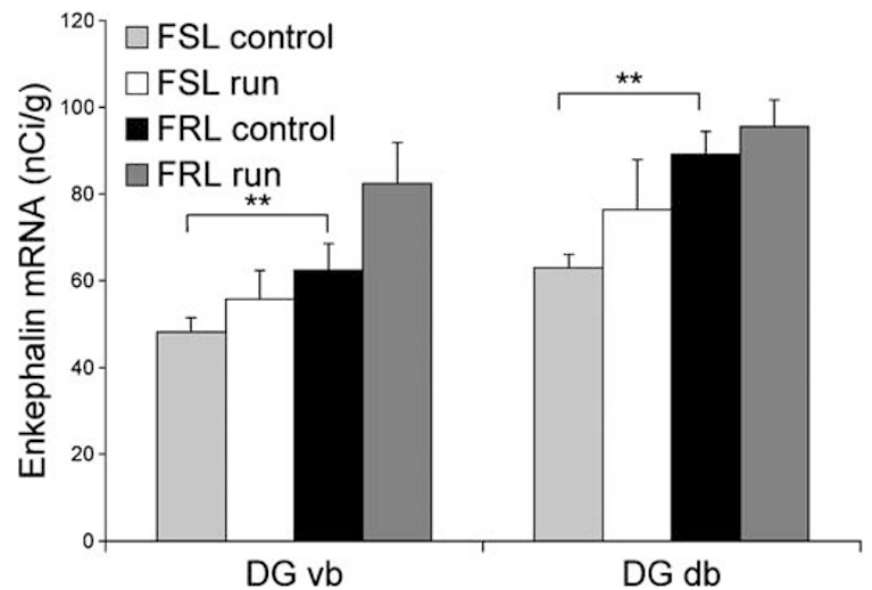

Figure 5 Hippocampal enkephalin mRNA expression in FSL and FRL rats after 5 weeks of running. Bar graphs illustrate enkephalin mRNA levels in the dorsal (DG db) and ventral blade (DG vb) of dentate gyrus in FSL and FRL rats with/without access to running-wheels ( $n=6-8 /$ group). FRL controls have a higher baseline level of enkephalin mRNA in dorsal and ventral blade of the dentate gyrus than FSL controls. Running did not change enkephalin mRNA levels in the dentate gyrus of FRL and FSL rats. Analyses were performed approximately at the level of Bregma -3.30 . Values are means $\pm S E M$. ${ }^{*} * 0.0 .01$ indicates a strain difference in enkephalin mRNA levels. DGvb, dentate gyrus ventral blade; DGdb, dentate gyrus dorsal blade.

\section{DISCUSSION}

Physical activity has an antidepressant effect in humans (Babyak et al, 2000; Martinsen, 1990) and an antidepressant-like effect in the 'depressed' FSL rats as assessed in the PST (Bjørnebekk et al, 2005). The antidepressant-like effect is associated with increased cell proliferation in the subgranular zone of the dentate gyrus (Bjørnebekk et al, 2005). In the present study we further analyzed whether there are differences in basal mRNA levels of NPY and opioid peptides enkephalin and dynorphin between the FSL and FRL rats in hippocampus and if running will alter expression of these neuropeptides in hippocampal subregions.

The Antidepressant-Like Effect of Running in FSL Rats is Associated with Increased NPY mRNA in Hippocampus, which is Correlated to Increased Cell Proliferation

Basal NPY mRNA level in the dentate gyrus was lower in the FSL compared to FRL rats. Following running there was a marked NPY mRNA increase in CA4 and the dentate gyrus in the FSL but not in FRL rats. In the FSL rats, running induced increase in NPY mRNA was strongly correlated to 
the running induced increase in cell proliferation (Bjørnebekk et al, 2005). Consequently, it is conceivable that NPY is one of the factors that trigger cell proliferation. Consistent with such reasoning is the finding that NPY increases adult neurogenesis in the olfactory bulb (Hansel et al, 2001b). Thus, NPY has the potential to increase neurogenesis in the adult brain.

The Y1 receptor, which promotes neurogenesis in olfactory neurons (Hansel et al, 2001a), is abundant in the hippocampus and it is possible that its stimulation by running in the dentate gyrus leads to increase in cell proliferation. However, additional studies are needed to ascertain this putative mechanism. Another possible interpretation of our data is that the increase in NPY and cell proliferation seen in FSL rats after running is caused by other variables not measured in this study. In either case, NPY and cell proliferation could be important targets for novel treatment of depression.

Humans studies have demonstrated decreased levels of NPY in the cerebrospinal fluid in depressed patients (Gjerris et al, 1992; Widerlov et al, 1988) and in postmortem brain tissue from suicide victims (Widdowson $e t$ al, 1992). However, conflicting results also exist (Berrettini et al, 1987). Antidepressants and ECT elevate NPY in human CSF and NPY, both protein and mRNA, in selected rat brain regions, predominantly in the hippocampal formation (Jiménez Vasquez et al, 2000a,b; Mathé et al, 1996; Nikisch et al, 2005). While ECT and ECS consistently increase NPY (Husum et al, 2000; Mathé et al, 1996; Mikkelsen et al, 1994; Stenfors et al, 1989; Zachrisson et al, 1995), the effects of antidepressants are more inconsistent (Bellmann and Sperk, 1993; Berrettini et al, 1987; Heilig et al, 1988). In both environmental and genetic animal models of depression, lower levels of NPY mRNA have been found in the CA region (Caberlotto et al, 1999; Husum and Mathé, 2002; Husum et al, 2002). In the present study, lower levels of NPY mRNA in the dentate gyrus were found in FSL rats, confirming the previous studies. Our data show that also running, which is antidepressant in humans (Babyak et al, 2000; Martinsen et al, 1989), increases the levels of NPY mRNA in the dentate gyrus and in the CA4 region of hippocampus in the 'depressed' FSL but not in the 'nondepressed' FRL rats. The increase in NPY mRNA does not seem to be dependent on running distance. NPY mRNA levels were not altered in the FRL that showed higher running behavior than the FSL strain. Thus, these two strains exhibit different response to running. These results further demonstrate that the same treatment or behavior can have different effects on NPY and highlight the importance of testing potential antidepressant treatments on depressed animals.

On the molecular level, this selective NPY regulation could be due to transcription factors acting directly on the NPY promoter such as NGFI-A, AP-1, AP-2, and retinoic acid, which might act with different potencies on the promoter of the NPY gene in the two strains (Buckland et al, 2004; Jalava and Mai, 1994; Li et al, 2000; Magni et al, 2000; Wernersson et al, 1998). Moreover, it is conceivable that there is a set of factors controlling basal transcription and another set that is induced after running. This might explain the finding that running induced increase in NPY mRNA in 'depressed' but not in 'nondepressed' animals.
Antidepressant-Like Effect of Running in FSL Rats is not Dependent on Regulation of Dynorphin and Enkephalin mRNAs

Dynorphin, another neuropeptide expressed in the dentate gyrus and striatum, is also involved in regulation of mood. Dynorphin agonists are dysphoric in humans (Pfeiffer $e t a l$, 1986). In the nucleus accumbens, kappa receptor agonists reduce dopamine release (Spanagel et al, 1992), whereas they inhibit excitatory glutamatergic neurotransmission in the hippocampus (Wagner et al, 1993). Recently, we demonstrated that running increases dynorphin mRNA in the dorsal striatum in FRL rats and in nucleus accumbens in both FRL and FSL rats (Bjørnebekk et al, 2005). In the present study we analyzed the effects of running in the two strains on dynorphin mRNA in hippocampus. Interestingly, basal dynorphin levels were higher in the dentate gyrus of FRL than FSL rats. After running, dynorphin mRNA was decreased in the FRL but not in the FSL strain. In hippocampus, dynorphinergic kappa receptors are localized on presynaptic terminals of the entorhinal cortex and also in the pyramidal cell layer (Mansour et al, 1988). In dorsal and ventral striatum kappa receptors are localized on presynaptic mesostriatal and mesolimbic nerve terminals. It is conceivable that the reduced hippocampal dynorphin mRNA after running in the FRL rats and the increased dynorphin mRNA in dorsal and ventral striatum reflect a functional adaptation in the limbic system at a network level. Thus in FRL rats, decreased dynorphin in hippocampus most likely reflects facilitation of hippocampal activity, which ultimately could potentiate learning and memory but has no effect on depression. On the other hand, increased dynorphin in ventral striatum implies that dynorphin mediates an inhibitory tone in the mesostriatal mesolimbic system. This inhibitory tone on the mesolimbic reward system could serve as a brake to inhibit the rats to develop a compulsive running behavior. The transcription factor CREB controls transcription of the preprodynorphin gene (Cole et al, 1995). Genetically engineered animals with increased levels of CREB in the nucleus accumbens also show increased immobility in the swim test. This can be counteracted by local administration of a kappa receptor antagonist, suggesting that the high immobility in the swim test in rodents with high CREB levels in nucleus accumbens is caused by an interaction of dynorphin and its receptor in nucleus accumbens (Pliakas et al, 2001). In hippocampus, the levels of dynorphin are increased after immobilization stress and after training in the learned helplessness paradigm. In this model, infusions of a kappa receptor antagonist into both nucleus accumbens and hippocampus result in improvement in the conditioned avoidance test (Shirayama et al, 2004). In our study, baseline level of dynorphin mRNA expression in the dentate gyrus was higher in the FRL compared to the FSL rats. After running, dynorphin mRNA levels were decreased in the dentate gyrus in FRL rats but not in the 'depressed' FSL rats. Therefore, we conclude that dynorphin mRNA regulation after running is not an important factor for the antidepressant-like effect of running or for increased cell proliferation in the FSL strain. On the other hand, and independently of depression, it is conceivable that there is a link between the amount of running and the degree of downregulation of dynorphin 
mRNA in the dentate gyrus. Kappa receptor activation will generate decreased cAMP levels, and thus downregulation of dynorphin could lead to increased activity and increased cAMP levels in cells expressing kappa receptors. In fact, in a previous study, we demonstrated that BDNF mRNA levels in the dentate gyrus were increased after running in FRL but not in FSL rats. One putative mechanism is that running downregulates kappa receptor activity leading to increased intracellular cAMP levels and increased BDNF transcription in hippocampus. In contrast to dynorphin, enkephalin potentiates LTP in hippocampus (Bramham et al, 1991). Most likely, enkephalin binds to mu and delta receptors on inhibitory GABAergic interneurons within the CA3 and CA1, thereby facilitating LTP in hippocampus via disinhibition of excitatory pyramidal neurons within CA3 and CA1. Broom et al (2002) reported that SCN80, a delta receptor agonist, increases climbing behavior but does not affect swimming in the PST. Since climbing activity primarily reflects the dopaminergic activity (Reneric and Lucki, 1998), these results probably indicate an interaction between the doapminergic and opioid system in the rewarding pathways.

In this context it is of interest that mice with a deletion of delta receptors show increased anxiety and 'depression' (Filliol et al, 2000). Moreover, delta receptor agonists and enkephalinase inhibitors modify the escape behavior in the learned helplessness model although at high doses they are also epileptogenic (Tejedor-Real et al, 1998). Under basal conditions, enkephalin mRNA expression in dentate gyrus is higher in the FRL than in the FSL rats. However, in contrast to dynorphin, enkephalin mRNA was not changed after running. Our results thus do not indicate that enkephalin is involved in regulating the increase in cell proliferation after running or that it plays a role in the antidepressant-like effect of running. However, they do raise the possibility that in the FSL strain, the low basal levels of enkephalin in hippocampus could be a factor contributing to the low cell proliferation and the state of depressive-like phenotype.

\section{Conclusion}

Accumulated evidence indicates that a dysregulation of the NPY system plays a role in pathophysiology of depression and that one mechanism of action shared by antidepressive treatments, pharmacological as well a physical, is enhancement of the NPYergic transmission (Mathé, 1999; Mathé et al, 1997, 1998, 1996, 2005). The increase of hippocampal NPY mRNA following wheel running found in this study is in line with this hypothesis and further extends it by demonstrating that physical activity that has antidepressive effects also enhances NPY expression in hippocampus. In addition, the demonstrated strong correlation between running induced cell proliferation and NPY mRNA suggests that increase in cell proliferation after antidepressive treatments could be stimulated by NPY.

\section{ACKNOWLEDGEMENTS}

This work was supported by the Swedish Research Council Grants 11642 and 10414, the National Institute on Drug
Abuse, the National Institute on Aging, and the Karolinska Institutet. None of the authors of this paper have any conflict of interest that might bias this work.

\section{REFERENCES}

Altman J (1962). Are new neurons formed in the brains of adult mammals? Science 135: 1127-1128.

Babyak M, Blumenthal JA, Herman S, Khatri P, Doraiswamy M, Moore $\mathrm{K}$ et al (2000). Exercise treatment for major depression: maintenance of therapeutic benefit at 10 months. Psychosom Med 62: 633-638.

Belke TW (1997). Running and responding reinforced by the opportunity to run: effect of reinforcer duration. J Exp Anal Behav 67: 337-351.

Bellmann R, Sperk G (1993). Effects of antidepressant drug treatment on levels of NPY or prepro-NPY-mRNA in the rat brain. Neurochem Int 22: 183-187.

Berrettini WH, Doran AR, Kelsoe J, Roy A, Pickar D (1987). Cerebrospinal fluid neuropeptide $\mathrm{Y}$ in depression and schizophrenia. Neuropsychopharmacology 1: 81-83.

Bjørnebekk A, Mathé AA, Brené S (2005). The antidepressant effect of running is associated with increased hippocampal cell proliferation. Int J Neuropsychopharmacol Mar 15: 1-12 [Epub ahead of print].

Blumenthal JA, Babyak MA, Moore KA, Craighead WE, Herman S, Khatri $\mathrm{P}$ et al (1999). Effects of exercise training on older patients with major depression. Arch Intern Med 159: 2349-2356.

Bramham CR, Milgram NW, Srebro B (1991). Delta opioid receptor activation is required to induce LTP of synaptic transmission in the lateral perforant path in vivo. Brain Res 567: 42-50.

Britton KT, Southerland S, Van Uden E, Kirby D, Rivier J, Koob G (1997). Anxiolytic activity of NPY receptor agonists in the conflict test. Psychopharmacology (Berl) 132: 6-13.

Broom DC, Jutkiewicz EM, Folk JE, Traynor JR, Rice KC, Woods JH (2002). Nonpeptidic delta-opioid receptor agonists reduce immobility in the forced swim assay in rats. Neuropsychopharmacology 26: 744-755.

Buckland PR, Hoogendoorn B, Guy CA, Coleman SL, Smith SK, Buxbaum JD et al (2004). A high proportion of polymorphisms in the promoters of brain expressed genes influences transcriptional activity. Biochim Biophys Acta 1690: 238-249.

Caberlotto L, Jiménez P, Hurd YL, Mathé AA, Fuxe K (1999). Alterations in neuropeptide $\mathrm{Y}$ levels and Y1 binding sites in the Flinders Sensitive Line rats, a genetic animal model of depression. Neurosci Lett 265: 191-194.

Cole RL, Konradi C, Douglass J, Hyman SE (1995). Neuronal adaptation to amphetamine and dopamine: molecular mechanisms of prodynorphin gene regulation in rat striatum. Neuron 14: $813-823$.

Douglass J, McMurray CT, Garrett JE, Adelman JP, Calavetta L (1989). Characterization of the rat prodynorphin gene. Mol Endocrinol 3: 2070-2078.

Fabel K, Tam B, Kaufer D, Baiker A, Simmons N, Kuo CJ et al (2003). VEGF is necessary for exercise-induced adult hippocampal neurogenesis. Eur J Neurosci 18: 2803-2812.

Filliol D, Ghozland S, Chluba J, Martin M, Matthes HW, Simonin F et al (2000). Mice deficient for delta- and mu-opioid receptors exhibit opposing alterations of emotional responses. Nat Genet 25: $195-200$.

Gjerris A, Widerlöv E, Werdelin L, Ekman R (1992). Cerebrospinal fluid concentrations of neuropeptide $\mathrm{Y}$ in depressed patients and in controls. J Psychiatry Neurosci 17: 23-27.

Gross CG (2000). Neurogenesis in the adult brain: death of a dogma. Nat Rev Neurosci 1: 67-73.

Hansel DE, Eipper BA, Ronnett GV (2001a). Neuropeptide Y functions as a neuroproliferative factor. Nature 410: 940-944. 
Hansel DE, Eipper BA, Ronnett GV (2001b). Regulation of olfactory neurogenesis by amidated neuropeptides. J Neurosci Res 66: 1-7.

Heilig M, Söderpalm B, Engel JA, Widerlöv E (1989). Centrally administered neuropeptide Y (NPY) produces anxiolytic-like effects in animal anxiety models. Psychopharmacology (Berl) 98: 524-529.

Heilig M, Wahlestedt C, Ekman R, Widerlöv E (1988). Antidepressant drugs increase the concentration of neuropeptide $\mathrm{Y}$ (NPY)-like immunoreactivity in the rat brain. Eur J Pharmacol 147: 465-467.

Heilig M, Zachrisson O, Thorsell A, Ehnvall A, Mottagui-Tabar S, Sjogren $\mathrm{M}$ et al (2004). Decreased cerebrospinal fluid neuropeptide $\mathrm{Y}$ (NPY) in patients with treatment refractory unipolar major depression: preliminary evidence for association with preproNPY gene polymorphism. J Psychiatr Res 38: 113-121.

Husum H, Mathé AA (2002). Early life stress changes concentrations of neuropeptide $\mathrm{Y}$ and corticotropin-releasing hormone in adult rat brain. Lithium treatment modifies these changes. Neuropsychopharmacology 27: 756-764.

Husum H, Mikkelsen JD, Hogg S, Mathe AA, Mork A (2000). Involvement of hippocampal neuropeptide $\mathrm{Y}$ in mediating the chronic actions of lithium, electroconvulsive stimulation and citalopram. Neuropharmacology 39: 1463-1473.

Husum H, Termeer E, Mathé AA, Bolwig TG, Ellenbroek BA (2002). Early maternal deprivation alters hippocampal levels of neuropeptide $\mathrm{Y}$ and calcitonin-gene related peptide in adult rats. Neuropharmacology 42: 798-806.

Husum H, Vasquez PA, Mathe AA (2001). Changed concentrations of tachykinins and neuropeptide $\mathrm{Y}$ in brain of a rat model of depression: lithium treatment normalizes tachykinins. Neuropsychopharmacology 24: 183-191.

Iversen IH (1993). Techniques for establishing schedules with wheel running as reinforcement in rats. J Exp Anal Behav 60: 219-238.

Jalava A, Mai S (1994). Fos and Jun form cell specific protein complexes at the neuropeptide tyrosine promoter. Oncogene 9: $2369-2375$.

Jiménez Vasquez PA, Salmi P, Ahlenius S, Mathé AA (2000a). Neuropeptide $\mathrm{Y}$ in brains of the Flinders Sensitive Line rat, a model of depression. Effects of electroconvulsive stimuli and d-amphetamine on peptide concentrations and locomotion. Behav Brain Res 111: 115-123.

Jiménez-Vasquez PA, Mathé AA, Thomas JD, Riley EP, Ehlers CL (2001). Early maternal separation alters neuropeptide $Y$ concentrations in selected brain regions in adult rats. Brain Res Dev Brain Res 131: 149-152.

Jiménez-Vasquez PA, Overstreet DH, Mathé AA (2000b). Neuropeptide $\mathrm{Y}$ in male and female brains of Flinders Sensitive Line, a rat model of depression. Effects of electroconvulsive stimuli. J Psychiatr Res 34: 405-412.

Larhammar D, Ericsson A, Persson H (1987). Structure and expression of the rat neuropeptide Y gene. Proc Natl Acad Sci USA 84: 2068-2072.

Lett BT, Grant VL, Koh MT (2001). Naloxone attenuates the conditioned place preference induced by wheel running in rats. Physiol Behav 72: 355-358.

Li BS, Kramer PR, Zhao W, Ma W, Stenger DA, Zhang L (2000). Molecular cloning, expression, and characterization of rat homolog of human AP-2alpha that stimulates neuropeptide Y transcription activity in response to nerve growth factor. $\mathrm{Mol}$ Endocrinol 14: 837-847.

Magni P, Beretta E, Scaccianoce E, Motta M (2000). Retinoic acid negatively regulates neuropeptide $\mathrm{Y}$ expression in human neuroblastoma cells. Neuropharmacology 39: 1628-1636.

Malberg JE, Eisch AJ, Nestler EJ, Duman RS (2000). Chronic antidepressant treatment increases neurogenesis in adult rat hippocampus. J Neurosci 20: 9104-9110.
Mansour A, Khachaturian $\mathrm{H}$, Lewis ME, Akil H, Watson SJ (1988). Anatomy of CNS opioid receptors. Trends Neurosci 11: 308-314.

Martinsen EW (1990). Benefits of exercise for the treatment of depression. Sports Med 9: 380-389.

Martinsen EW, Hoffart A, Solberg O (1989). Comparing aerobic with nonaerobic forms of exercise in the treatment of clinical depression: a randomized trial. Comp Psychiatry 30: 324-331.

Martinsen EW, Medhus A, Sandvik L (1985). Effects of aerobic exercise on depression: a controlled study. Br Med J (Clin Res $E d n)$ 291: 109.

Mathé AA (1999). Neuropeptides and electroconvulsive treatment. J ECT 15: 60-75.

Mathé AA, Andersson W, Angelucci F, El Khoury A, Gruber SHM, Husum $\mathrm{H}$ et al (2005). Search for biological correlates of depression and mechanisms of action of antidepressant treatment modalities. Do neuropeptides play a role? Physiol Behav, in press.

Mathé AA, Gruber S (2004). Neuropeptide Y has marked antidepressant properties in a rat model of depression. Neuropsychopharmacology 29(Suppl): 154.

Mathé AA, Gruber S, Jiménez PA, Theodorsson E, Stenfors C (1997). Effects of electroconvulsive stimuli and MK-801 on neuropeptide $\mathrm{Y}$, neurokinin $\mathrm{A}$, and calcitonin gene-related peptide in rat brain. Neurochem Res 22: 629-636.

Mathé AA, Jimenéz PA, Theodorsson E, Stenfors C (1998). Neuropeptide $Y$, neurokinin A and neurotensin in brain regions of Fawn Hooded 'depressed', Wistar, and Sprague Dawley rats. Effects of electroconvulsive stimuli. Prog Neuropsychopharmacol Biol Psychiatry 22: 529-546.

Mathé AA, Jousisto-Hanson J, Stenfors C, Theodorsson E (1990). Effect of lithium on tachykinins, calcitonin-gene-related peptide, and neuropeptide $Y$ in rat brain. $J$ Neurosci Res 26: 233-237.

Mathé AA, Norstedt Wikner B, Stenfors C, Theodorsson E (1994). Effects of lithium on neuropeptide $\mathrm{Y}$, neurokinin $\mathrm{A}$ and substance $\mathrm{P}$ in brain and peripheral tissues of rat. Lithium 5: 241-247.

Mathé AA, Rudorfer MV, Stenfors C, Manji HK, Potter WC, Theodorsson E (1996). Effects of electroconvulsive treatment on somatostatin, neuropeptide $\mathrm{Y}$, endothelin and neurokinin. A concentration in cerebrospinal fluid of depressed patients. Depression 3: 250-256.

Mikkelsen JD, Woldbye D, Kragh J, Larsen PJ, Bolwig TG (1994). Electroconvulsive shocks increase the expression of neuropeptide Y (NPY) mRNA in the piriform cortex and the dentate gyrus. Brain Res Mol Brain Res 23: 317-322.

Nikisch G, Ågren H, Chin B, Czernik A, Baumann P, Mathé AA (2005). Neuropeptide $Y$ and corticotropin-releasing hormone in CSF mark response to antidepressant treatment with citalopram. Int J Neuropsychopharmacol Mar 23: 1-8 [Epub ahead of print].

Nilsson C, Karlsson G, Blennow K, Heilig M, Ekman R (1996). Differences in the neuropeptide Y-like immunoreactivity of the plasma and platelets of human volunteers and depressed patients. Peptides 17: 359-362.

Overstreet DH (1993). The Flinders sensitive line rats: a genetic animal model of depression. Neurosci Biobehav Rev 17: 51-68.

Overstreet DH, Pucilowski O, Rezvani AH, Janowsky DS (1995). Administration of antidepressants, diazepam and psychomotor stimulants further confirms the utility of Flinders Sensitive Line rats as an animal model of depression. Psychopharmacology (Berl) 121: 27-37.

Overstreet DH, Russell RW, Helps SC, Messenger M (1979). Selective breeding for sensitivity to the anticholinesterase DFP. Psychopharmacology (Berl) 65: 15-20.

Persson AI, Thorlin T, Bull C, Zarnegar P, Ekman R, Terenius L et al (2003). Mu- and delta-opioid receptor antagonists decrease proliferation and increase neurogenesis in cultures of rat adult hippocampal progenitors. Eur J Neurosci 17: 1159-1172. 
Pfeiffer A, Brantl V, Herz A, Emrich HM (1986). Psychotomimesis mediated by kappa opiate receptors. Science 233: 774-776.

Pliakas AM, Carlson RR, Neve RL, Konradi C, Nestler EJ, Carlezon Jr WA (2001). Altered responsiveness to cocaine and increased immobility in the forced swim test associated with elevated cAMP response element-binding protein expression in nucleus accumbens. J Neurosci 21: 7397-7403.

Pucilowski O, Overstreet DH, Rezvani AH, Janowsky DS (1993). Chronic mild stress-induced anhedonia: greater effect in a genetic rat model of depression. Physiol Behav 54: 12151220.

Russell RW, Overstreet DH, Messenger M, Helps SC (1982). Selective breeding for sensitivity to DFP: generalization of effects beyond criterion variables. Pharmacol Biochem Behav 17: 885-891.

Santarelli L, Saxe M, Gross C, Surget A, Battaglia F, Dulawa S et al (2003). Requirement of hippocampal neurogenesis for the behavioral effects of antidepressants. Science 301: 805-809.

Shirayama Y, Ishida H, Iwata M, Hazama GI, Kawahara R, Duman RS (2004). Stress increases dynorphin immunoreactivity in limbic brain regions and dynorphin antagonism produces antidepressant-like effects. J Neurochem 90: 1258-1268.

Spanagel R, Herz A, Shippenberg TS (1992). Opposing tonically active endogenous opioid systems modulate the mesolimbic dopaminergic pathway. Proc Natl Acad Sci USA 89: 2046-2050.

Stenfors C, Theodorsson E, Mathé AA (1989). Effect of repeated electroconvulsive treatment on regional concentrations of tachykinins, neurotensin, vasoactive intestinal polypeptide, neuropeptide $\mathrm{Y}$, and galanin in rat brain. J Neurosci Res 24: 445-450.

Stogner KA, Holmes PV (2000). Neuropeptide-Y exerts antidepressant-like effects in the forced swim test in rats. Eur $J$ Pharmacol 387: R9-10.

Strawbridge WJ, Deleger S, Roberts RE, Kaplan GA (2002). Physical activity reduces the risk of subsequent depression for older adults. Am J Epidemiol 156: 328-334.

Tejedor-Real P, Mico JA, Smadja C, Maldonado R, Roques BP, Gilbert-Rahola J (1998). Involvement of delta-opioid receptors in the effects induced by endogenous enkephalins on learned helplessness model. Eur J Pharmacol 354: 1-7. van Praag H, Christie BR, Sejnowski TJ, Gage FH (1999). Running enhances neurogenesis, learning, and long-term potentiation in mice. Proc Natl Acad Sci USA 96: 13427-13431.

Wagner JJ, Terman GW, Chavkin C (1993). Endogenous dynorphins inhibit excitatory neurotransmission and block LTP induction in the hippocampus. Nature 363: 451-454.

Werme M, Messer C, Olson L, Gilden L, Thoren P, Nestler EJ et al (2002). Delta FosB regulates wheel running. J Neurosci 22: 8133-8138.

Werme M, Thoren P, Olson L, Brené S (1999). Addiction-prone Lewis but not Fischer rats develop compulsive running that coincides with downregulation of nerve growth factor inducible-B and neuron-derived orphan receptor 1. J Neurosci 19: 6169-6174.

Werme M, Thoren P, Olson L, Brené S (2000). Running and cocaine both upregulate dynorphin mRNA in medial caudate putamen. Eur J Neurosci 12: 2967-2974.

Wernersson J, Johansson I, Larsson U, Minth-Worby C, Pahlman S, Andersson G (1998). Activated transcription of the human neuropeptide Y gene in differentiating SH-SY5Y neuroblastoma cells is dependent on transcription factors AP-1, AP-2alpha, and NGFI. J Neurochem 70: 1887-1897.

West MJ, Slomianka L, Gundersen HJ (1991). Unbiased stereological estimation of the total number of neurons in the subdivisions of the rat hippocampus using the optical fractionator. Anat Rec 231: 482-497.

Widdowson PS, Ordway GA, Halaris AE (1992). Reduced neuropeptide $Y$ concentrations in suicide brain. J Neurochem 59: 73-80.

Widerlov E, Lindstrom LH, Wahlestedt C, Ekman R (1988). Neuropeptide Y and peptide YY as possible cerebrospinal fluid markers for major depression and schizophrenia, respectively. J Psychiatr Res 22: 69-79.

Woldbye DP, Nanobashvili A, Husum H, Bolwig TG, Kokaia M (2002). Neuropeptide Y inhibits in vitro epileptiform activity in the entorhinal cortex of mice. Neurosci Lett 333: 127-130.

Zachrisson O, Mathé AA, Stenfors C, Lindefors N (1995). Limbic effects of repeated electroconvulsive stimulation on neuropeptide $\mathrm{Y}$ and somatostatin mRNA expression in the rat brain. Brain Res Mol Brain Res 31: 71-85.

Zurawski G, Benedik M, Kamb BJ, Abrams JS, Zurawski SM, Lee FD (1986). Activation of mouse T-helper cells induces abundant preproenkephalin mRNA synthesis. Science 232: 772-775. 